\title{
THE ASYMMETRIC EFFECT OF INSTITUTIONAL QUALITY ON CHINESE OUTWARD REAL ESTATE INVESTMENT
}

\author{
Jingjing ZHANG ${ }^{1}$, Chyi Lin $\mathrm{LEE}^{2, *}$, Nelson $\mathrm{CHAN}^{2}$ \\ ${ }^{1}$ Nanjing Audit University, Institute for Social and Economic Research, Nanjing, China \\ 2 Western Sydney University, School of Business, Locked Bag 1797, Penrith NSW 2751, Australia
}

Received 20 November 2018; accepted date 07 May 2019

\begin{abstract}
Chinese outward investment in real estate (FDIRE) has increased tremendously in recent years. However, it has attracted little attention in the literature. This study aims to assess the asymmetric impact of institutional quality on Chinese outward FDIRE using an extended gravity model with a real estate institutional factor. Using the unique dataset of Chinese outward real estate investment collected from Real Capital Analytics, we identify the main determinants of China's outward FDIRE. The results show that the established gravity model and real estate institutional factor together explain China's outward FDIRE. Specifically, market size and cultural proximity have a positive influence on the FDIRE outflows from China. In addition, institutional factor, namely real estate transparency, has an acute impact on China's outward FDIRE, whilst it is conditional on the market size of and the economic growth speed of a country, highlighting an asymmetric effect of institutional quality on Chinese outward FDIRE. The implications of the findings have also been discussed.
\end{abstract}

Keywords: cross border real estate investment, real estate transparency, sectoral analysis, institutional quality, asymmetry, China, foreign direct investment (FDI).

\section{Introduction}

As at December 2016, China has become the second largest international investor (behind the United States) in the world with US $\$ 183$ billion, contributing to $11.6 \%$ of the world's overall outward investment (UNCTAD, 2017). The growth of Chinese outward foreign direct investment (OFDI) has received increasing attention in the literature (Buckley et al., 2007; Kolstad \& Wiig, 2012; Quer, Claver, \& Rienda, 2012). However, by employing an aggregate dataset with all sectors, their results on Chinese OFDI are mixed. Particularly, no consensus is available on the impact of institutional quality on China's OFDI. The mixed findings probably can be attributed to the difficulty and/or insufficient control for industry characteristics. As discussed by Deng, Wong, and Chau (2018), each industry has its own set of formal and informal rules; thereby a panel model cannot fully control the industries' effect if industries and institutional information environments vary together. To overcome the limitation of industry characteristics, this study investigates Chinese OFDI using a sectoral analysis. Specifically, we confine our analysis to China's outward FDI in a single sector, which is real estate.
Importantly, the total value of Chinese outward real estate investment (FDIRE) in the global real estate market has increased by 33 times over 2007-2016 (RCA, 2017) (see Figure 1). Figure 2 also depicts that Chinese FDIRE recorded high annual growth rates over 2008-2016, ranging from 19 per cent to 365 per cent. The only exceptions were in 2008 ( -79.9 per cent; global financial crisis) and 2014 (-2 per cent). This sees China as one of the world's largest international property investors (CBRE, 2015; Knight Frank, 2015). The trend of expanding Chinese outward FDIRE is consistent with the "One belt, one road" initiative. Specifically, the Chinese central government has urged state firms to invest aboard by providing financing support and easing of overseas investment policies (Tiezzi, 2014; KnightFrank, 2015). While Chinese outbound real estate investment may slow in the near term as the Chinese government updated guidelines on foreign investment in August 2017 to curb "irrational" outbound investment, industrial properties such as logistics, high-tech manufacturing and business park space may be still favoured under the "One belt, one road" initiative (Cushman \& Wakefield, 2018). This further highlights the importance of understanding Chinese outward real estate investment.

*Corresponding author. E-mails: c.lee@westernsydney.edu.au; chyilin2000@hotmail.com 


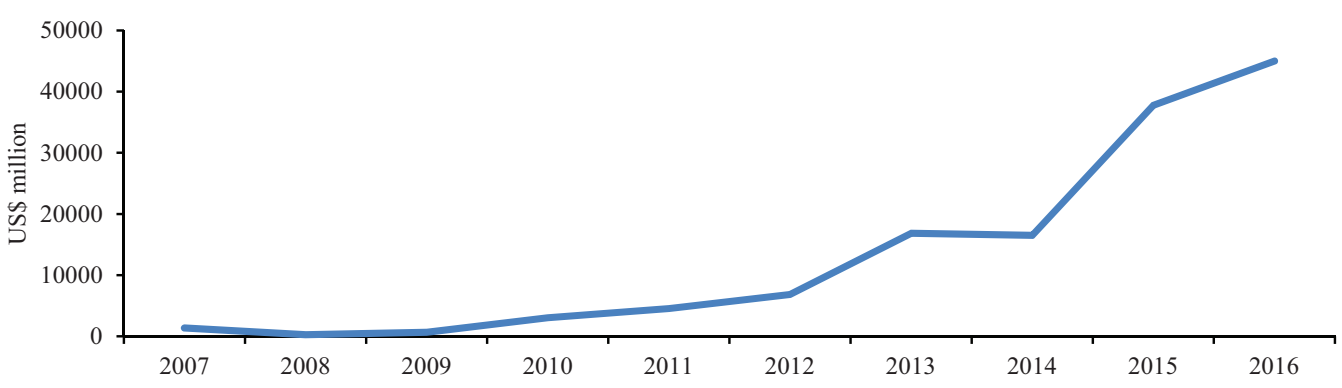

Figure 1. Chinese outward real estate investment (source: Real Capital Analytics [RCA], 2017)

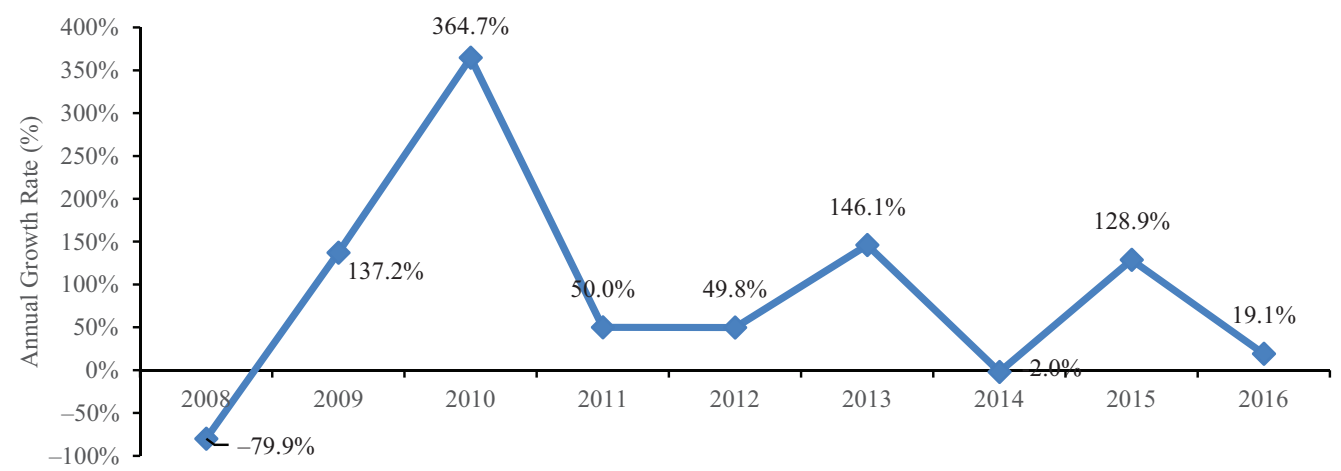

Figure 2. Chinese FDIRE annual growth rate (\%) (source: RCA, 2017)

To date, however, research of China's international real estate investment is scarce. To fill this gap, we develop an extended gravity-institutional model to analyse the determinants of Chinese outward FDIRE in a panel form. By recognising the unique characteristics of real estate investment, we also incorporate a real estate institutional factor, namely real estate transparency index, in assessing the determinants of Chinese international property investment. This study therefore contributes to the literature in a number of ways. Firstly, although institutional quality has become increasingly relevant for FDI decisions since the 1990s (Dunning, 1998), most studies did not consider the asymmetric effect of institutional quality. Recently Alexsynska and Havrylchnyk (2013) suggested that institutional quality has an asymmetric impact on emerging and developed foreign investors. However, they qualified the finding of institutional asymmetry to the endowment of natural resources. To shed more light on it, a study that confines to a single sector, particularly real estate that is not very related to natural resources endowment, is paramount. Real estate, unlike other sectors (e.g. energy, resources and mining etc), is not very sensitive to the availability of natural resources endowments ${ }^{1}$. Specifically, to the best of our knowledge, this study is the first study to examine the asymmetric effect of institutional quality on Chinese outbound FDI. Besides, transparency level of a

\footnotetext{
1 We need to qualify that real estate sector is not very related to the endowment of natural resources, but it does not mean that natural resources endowments are completely unrelated to real estate. We thank the referee for highlighting this point.
}

property market is used as a measurement of institutional quality (see section 3 for the discussion of the transparency index). Particularly, driven by their prior knowledge of the complex real estate investment environment in an emerging market, institutional quality is more likely to have an asymmetric effect on China's FDIRE. A dedicated study of Chinese outward real estate investment therefore provides further insights into the driving forces of Chinese cross-border real estate investment in general and the asymmetric impact of institutional quality in particular. Secondly, to the best of our knowledge, this is the first sectoral study to examine the determinants of Chinese OFDI, particularly Chinese international real estate investment. Using the unique dataset from Real Capital Analytics concerning with cross-border real estate investment, this allows us to examine the determinants of Chinese OFDI into a particular sector, i.e. real estate, for the first time. This offers a rigorous foundation for policy formulation. Thirdly, this research contributes to the limited studies on FDIRE. In this study, we examined China's outward FDIRE for the first time. Specifically, it provides some empirical evidence whether the results in the general business literature can be generalised to all markets and sectors, including emerging markets and all sectors.

The remainder of the study is structured as follows. Section 1 reviews the previous related studies on Chinese FDI and FDIRE, as well as the asymmetric impact of institutional quality on FDIRE. Section 2 develops an extended gravity model which provides the theoretical foundation for the empirical study. Section 3 discusses the dataset and the models to investigate the determinants of Chinese 
outward FRIRE. Results of the model are reported and discussed in Section 4. We draw up conclusions and the implications of the study in the last section.

\section{Literature review}

This section critically reviews the related studies on Chinese outward FDI in general and the asymmetric effect of institutional quality on China's outward FDI in particular. In addition, previous studies on international real estate investment are also critically examined.

\subsection{The uniqueness of Chinese outward FDI}

Extensive general business studies have investigated the drivers of Chinese outward FDI. For instance, a seminal paper, Buckley et al. (2007) found that OFDI from China is related to cultural proximity, geographical proximity and market size of the host markets, as well as endowment of natural resources and institutional governance. Interestingly, unlike previous studies on OFDI, they found that the conventional general theory (e.g. the gravity model), which is developed mainly based on developed markets, cannot fully explain the case of an emerging market like China. Indeed, the general theory should incorporate a special theory to explain Chinese firms' international investment. Quer et al. (2012) investigated the OFDI of the largest 35 mainland Chinese firms over 2002-2009. Their results showed that the conventional model does not directly apply to Chinese firms. They also found that cultural proximity to China is a key driver in assisting Chinese investors to overcome the possible cultural barrier.

Blomkvist and Drogendijk (2013) found that certain, not by all, psychical or geographical distance indicators such as language and culture distance, the level of industrialisation, as well as the level of democracy are critical explanatory factors for Chinese firm's investment abroad, highlighting that the general theories are not universal concepts and the importance of dedicated studies for emerging markets such as China. Numerous studies have demonstrated the special characteristics of Chinese outward FDI. In particular, Chinese firms have a distinctive foreign investment strategy in response to the imperfections of the Chinese capital market, which offers finance at below-market rates for Chinese investors and firms (Buckley et al., 2007; Kolstad \& Wiig, 2012). Further, Chinese investors have also developed ownership advantages that accrue from their home country (e.g. flexibility and prior knowledge of the complex operation in an emerging market) (Dunning, 2002; Erdener \& Shapiro, 2005). Specifically, Chinese firms tend to do business with each other, forming an integrated business network system. Unlike many Western countries, this networking system is a key success factor for many Chinese businesses. In addition, Chinese firms might also cultivate strong personal and economic ties to individual political leaders (Yeung, 1999). Therefore, it is reasonable to find that Chinese outward-investing behaviour would be different compared with investors from developed markets.
Overall, extensive studies have considered the conventional models such as the gravity model and the quality of institutions (i.e. governance) in explaining Chinese outward FDI, whilst there is no evidence to suggest that these theories are directly applicable in the Chinese context (an emerging market). This also highlights the uniqueness of Chinese outward-investing behaviour.

\subsection{Asymmetric effect of institutional quality on Chinese outward FDI}

Given the uniqueness of Chinese outward-investing behaviour, this section examines the asymmetric effect of institutional quality on Chinese OFDI. In general, the asymmetric impact of institutional quality on FDI is a relatively unexplored topic in the literature. Several studies found that the lack of quality institutions of a host country might not necessarily deter capital flow from China (Buckley et al., 2007; Quer et al., 2012); this is not in line with the main established thesis in international business that an enhanced institutional arrangement, such as political stability, an established law and order system, sound property rights and low corruption would significantly increase the inflow of FDI (Globerman \& Shapiro, 2002).

Recent studies have directed attention to the asymmetric effect of institutional quality by distinguishing between developed and developing source countries. Alexsynska and Havrylchnyk (2013) found that institutional quality has an asymmetric effect, depending on source countries, on the flow of FDI. Specifically, investors from developed and emerging markets react asymmetrically to good institutional quality. They also discovered that the significance of institutional quality on aggregate investment flows will diminish if host countries are endowed with large reserves of natural resources. On the other hand, Lucke and Eichler (2016) offered some empirical evidence to support the notion of asymmetric impact of institutional quality depending on FDI destinations.

Importantly, the asymmetric issue is particularly relevant to Chinese outward real estate investment. Firstly, China is still an emerging market; thereby institutional quality could have an asymmetric effect on Chinese outward investment compared with the western counterpart. As discussed by Alexsynska and Havrylchnyk (2013), investors from emerging economies (e.g. China) would prefer countries with the highest institutional quality if they invest in developed economies with better institutions, whilst they prefer countries with similar and only marginally worse institutions if those investors invest in host countries with worse institutions than their own countries. Further, Chinese investors who have prior knowledge of the complex operation environment in an emerging market (Dunning, 2002) might have, fully or partly, prepared for this complex real estate investment environment. This could provide some indirect evidence to explain the findings of Buckley et al. (2007) and Blomkvist and Drogendijk (2013) that high Chinese investment flows to countries with poor quality of institutions. To sum up, institutional 
quality could have an asymmetric impact on FDI flows in general and Chinese outward real estate investment in particular due to Chinese investors' prior knowledge of the operation in an emerging real estate market.

\subsection{Cross-border real estate investment}

Several property studies have discussed the impact of FDI on the Chinese property market and the barriers for foreigners to enter the Chinese property market (Jiang, Chen, \& Isaac, 1998; Zhu, Sim, \& Zhang, 2006). He, Wang, and Cheng (2009) investigated the trend of inward FDIRE to different Chinese provinces during the period 2000-2007. The study considered how FDI location selection is affected by provincial characteristics, including regional governance, local market condition and housing reforms, as well as land commercialisation. He and Zhu (2010) found that foreign investors prefer to invest in larger Chinese cities with larger number of foreign investments, population and tourists.

Hui and Chan (2014) revealed empirical evidence to suggest that inward of FDIRE to China is largely concentrated in coastal areas. It can also be explained by the number of foreign real estate enterprises and GDP per capita. Rodriguez and Bustillo (2010) used time series data from 1990 to 2007 and documented that a number of variables can be used to explain the inflow of FDIRE in Spain. Importantly, these factors consist of certain property specific explanatory variables, including housing prices, GDP per capita, travel costs and expected gains in capital, as well as tourism agglomeration. More recently, Farzanegan and Fereidouni (2014) suggested that FDIRE is affected by GDP per capita, FDI in other sectors and property prices. Surprisingly, they found that real estate transparency itself is not a critical factor, whilst it only affects foreign inward real estate investment in richer markets. In addition, Rogers, Lee, and Yan (2015) discussed local resistance towards Chinese foreign housing investment.

Overall, numerous studies have examined the determinants of Chinese OFDI, but no study has been undertaken on the driving forces of Chinese outward FDIRE. Although a growing body of literature has been devoted to institutional quality, little studies have focused on the asymmetric effect of institutional quality and previously documented findings of institutional quality asymmetry are qualified to the endowment of natural resources. Therefore, a study confines to a single sector, real estate, is paramount.

\section{Theoretical framework}

Using an extended gravity model with an institutional factor, this section develops a theoretical model to investigate the factors that may have some impact on Chinese investors' FDIRE decision making. The gravity model has been widely used in examining the determinants of different types of flow between two economies, such as foreign direct investment (Anderson, 2011). It is posited that the economic connection between two economies is proportional to economic size and inversely related to trade barriers or distance. The proxy for barrier between two economies, includes geographical distance, cultural proximity and policy barriers (Anderson \& Wincoop, 2004). By applying the gravity equation in explaining FDI, it could be written as follows:

$$
F D I_{i j}=f\left(Y_{i}, Y_{j}, \text { barrier }_{i j}\right) \text {, }
$$

where: $F D I_{i j}$ is the bilateral flow of investment between country $i$ and country $j$; $Y$ is the size of economy which is usually measured by GDP; barrier $_{i j}$ represents the FDI barriers between country $i$ and country $j$.

Although numerous studies have investigated the determinants of Chinese outward FDI, the documented evidence is not universal. This can be attributed to the use of aggregated FDI data that may distort the in-depth relationship between FDI and its determinants (Shah, Ahmad, \& Ahmed, 2016). This highlights the importance of a sectoral study with a clear focus on a particular sector in order to provide a rigorous foundation for policy formulation. To address it, we employed the unique dataset from Real Capital Analytics that tracking Chinese outward real estate investment ${ }^{2}$.

Acknowledging the uniqueness of real estate investment, institutional factor, measuring by transparency level of a real estate market ${ }^{3}$, has been introduced into the traditional gravity model. Importantly, the transparency level of a real estate market could be a key barrier in affecting cross-border real estate investment. Given property markets are characterised with strong heterogeneity and highly localised, as well as with information asymmetry problem, uncertainty regarding foreign real estate investment laws and market information could also weaken foreign

\footnotetext{
2 Real estate sector is selected for a number of reasons. Firstly, real estate is a unique asset with special characteristics (e.g. limited land supply and inelastic building supply). In addition, real estate investment is highly localised with strong heterogeneity and segmented among different countries. This suggests that international real estate investment is potentially more susceptible to an institutional factor, which is the variable of interest of this study. Secondly, the real estate sector has figured prominently in China's economy as the real estate sector is ranked the top three among all sectors listed on the Shanghai and Shenzhen stock exchanges (Deng et al., 2018; Liu, Shrestha, Martek, \& Zhou, 2018). Lastly, driven by high expected returns on real estate, more than half of listed nonreal estate firms in China, taking advantages of their excess capacities in productive factors, have diversified into the real estate sector (Rong, Wang, \& Gong, 2015; Huang \& Rong, 2017). This sees the strong appetite of real estate investment from both Chinese real estate and non-real estate companies.

3 Although the transparency index for real estate covers a number of broader aspects such as market fundamentals, governance, regulatory and legal, performance, transaction process and sustainability (JLL, 2018), it could mean different from the conventional definition of the institutional quality such as the openness of an economy.
} 
investor confidence. Therefore, the increased transparency reduces the information asymmetry problem and allows for better risk management, as well as facilitates international real estate investment (Chin, Dent, \& Roberts, 2006; Falkenbach, 2009; Eichholtz, Gugler, \& Kok, 2011). In other words, proxies for investment barriers include geographical distance between two economies, cultural proximity, which is measured by the use of common language, and the institutional quality of the host country.

Since this study assesses the determinants of China's outward FDI flow to different host countries, Equation (1) can be rewritten as follows:

$$
\text { REFDI }_{j}=g\left(Y_{j}, \text { distance }_{j}, \text { common language }_{j}, \text { RE institution }_{j}\right) \text {, }
$$

where: $R E F D I_{j}$ is China's FDI in real estate market of host country $j ; Y_{j}$ is the economic size of host country $j$; distance ${ }_{j}$ measures the distance between country $i$ and country $j$; commonlanguage ${ }_{j}$ indicates whether the host country $j$ uses Chinese as one of its official languages, and REinstitution $_{j}$ is real estate institutional quality of host country $j$. Based on the abovementioned theoretical analysis, we empirically estimate the determinants of China's outward real estate investments.

\section{Empirical framework}

\subsection{Data and explanatory variables}

To assess the determinants of Chinese outward FDIRE, we collect the data of annual outward FDIRE transactions from China to 45 economies over the study period from 2007 to $2016^{4}$. These economies include the largest economies in the world such as the US and Japan, and China's major trading partners, for example Taiwan, Australia, as well as emerging markets such as Poland, Sri Lanka and Russia etc. Appendix (Table A1) reports the full list of sample countries. The data of Chinese outward FDIRE was collected from Real Capital Analytics (RCA). RCA tracks all individual commercial real estate transactions over US\$5 million (e.g. office, retail, industrial, hotel and so on) globally, particularly cross border real estate investments. Specifically, it tracks Chinese institutional investors' foreign real estate investment. This unique dataset al. ows us to examine Chinese institutional investors' outward FDIRE for the first time ${ }^{5}$.

4 We commenced the analysis from 2007 as no significant Chinese cross-border investment was observed prior to 2007 from the RCA database.

5 RCA does not consider infrastructure projects, although it includes industrial properties. We attempted to find the related infrastructure data from other datasets (e.g. MSCI/IPD). Although the MSCI/IPD offers infrastructure funds' performance indices, it does not offer any FDI data regarding infrastructure projects. This limitation of data should be borne in mind. Thanks to the referee for highlighting this point. This limitation should be borne in mind.
Based on the extended-gravity model as discussed in section 3 and the related literature, a set of explanatory variables are taken into consideration. The explanatory variables include (i) gravity-related variables (i.e., GDP, geographic distance and cultural proximity); (ii) institutional factor (i.e., real estate transparency) and (iii) real estate market specific variables (i.e., GDP per capita growth rate, housing prices ${ }^{6}$, interest rate and population growth). The definitions of the explanatory variables are discussed in the following section and summarised in Table 1.

\section{Gravity-related factors}

The traditional gravity model suggests that both economic mass and geographic distance are the determinants of international economic relationship. It is hypothesised that GDP has a positive effect on FDIRE in response to large economies commonly have larger investment opportunities; thereby these economies are preferred. This is also known as the market-seeking FDI hypothesis (Buckley et al., 2007; He et al., 2009; Rodriguez \& Bustillo, 2010; Farzanegan \& Fereidouni, 2014; Hui \& Chan, 2014). We therefore conjecture that host countries' GDP has positive impact on China's outward FDIRE. Annual GDP which gauges the economic scale of host countries is collected from the World Development Index (WDI); a database that is supported by the World Bank (WB).

Geographic distance is another widely used explanatory factor of FDI flows under the gravity framework. It asserts that firms usually prefer locations close to their home markets to commence their international operations; thereby geographic distance and FDI flow are negatively associated (Lau, 2003). But numerous property studies have demonstrated the importance of geographical diversification strategy (Lee, Robinson, \& Reed, 2008; Byrne \& Lee, 2009). Hence, unlike the general business literature, we expect the geographic distance from China might not have a significant negative impact on Chinese investment in real estate abroad. To measure the physical distance between China and host markets, bilateral distance between the host country and China was utilised. The data were obtained from CEPII (Centre d'Etudes Propectives et d'Informations Internationales) dataset.

In addition, we used the data from CEPII to measure cultural proximity in which it is measured by whether or not the host country and China use the same language. A host country is expected to have little cultural distance with China if Chinese is one of the official languages of the host market. As discussed by Buckley et al. (2007), cultural proximity has a significant and positive impact on

\footnotetext{
${ }^{6}$ Housing prices are used to gauge the performance of real estate market due to several reasons. First, the indices of commercial properties, in general, are appraised based indices and subject to smoothing bias (Newell \& Lee, 2011). Second, many emerging markets (e.g. Kenya) do not offer an index of direct commercial property. Third, housing price is used by previous property studies (e.g. Farzanegan \& Fereidouni, 2014; Hui \& Chan, 2014).
} 
Table 1. Sources of data

\begin{tabular}{|c|c|c|c|}
\hline Variable & Measure & Source & Expected sign \\
\hline \multicolumn{4}{|c|}{ Panel A: Dependent variable } \\
\hline $\begin{array}{l}\text { FDIRE } \\
\text { (FDIRE) }\end{array}$ & $\begin{array}{l}\text { China's outward real estate } \\
\text { investment (USD) in million }\end{array}$ & Real Capital Analytic & \\
\hline \multicolumn{4}{|c|}{ Panel B: Explanatory variables } \\
\hline \multicolumn{4}{|l|}{ Gravity-related factors } \\
\hline GDP $(G D P)$ & $\begin{array}{l}\text { GDP of host countries (USD) in } \\
\text { billion }\end{array}$ & World Data Bank & + \\
\hline Distance & $\begin{array}{l}\text { Geographic distance between host } \\
\text { countries and Beijing, China }\end{array}$ & CEPII & - \\
\hline Cultural proximity (Language) & $\begin{array}{l}\text { Dummy variable: } 1 \text { suggests that } \\
\text { Chinese is one of official language(s) } \\
\text { of host countries; otherwise } 0\end{array}$ & CEPII & + \\
\hline \multicolumn{4}{|l|}{ Institutional factor } \\
\hline Real estate transparency (RETrans) & $\begin{array}{l}\text { Global Real Estate Transparency } \\
\text { Index }\end{array}$ & Jones Lang LaSalle & - \\
\hline \multicolumn{4}{|l|}{ Real estate market specific variables } \\
\hline GDP per capita growth (GDPp) & GDP per capita growth rate & World Data Bank & + \\
\hline Housing price $(H P)$ & Housing price growth rate & $\begin{array}{l}\text { International Bank of } \\
\text { Settlement }\end{array}$ & + \\
\hline Interest (Int) & Nominal interest rate & DataStream & - \\
\hline Population ( $p o p)$ & Population growth rate & World Data Bank & \\
\hline
\end{tabular}

Chinese overall OFDI over 1984-2001. Specifically, strong ties and networks among mainland Chinese and overseas Chinese are critical successful factors for mainland Chinese investors to reduce their business risk (Erdener \& Shapiro, 2005) and identify suitable investment opportunities (Zhan, 1995) in certain foreign markets. Hence, we expect that the level of cultural proximity in the host market has a positive impact on the Chinese outward FDIRE.

\section{Institutional quality}

Institutional quality has been measured by political stability, established law and order system, sound property rights and low corruption (Globerman \& Shapiro, 2002). But, these broader indicators largely ignored a fact that transaction process of real estate investment could be lengthy and real estate transparency could be low in some countries even though these are developed markets (e.g. South Korea). Importantly, these would hinder cross boarder real estate investment. To address it, the Jones Lang LaSalle (JLL) Global Real Estate Transparency Index (GRETI) was used to measure the transparency levels of property markets in the host countries. GRETI demonstrates the transparency level of global property markets. GRETI is based on the combination of quantitative market data along with survey data from different markets. GRETI is scaled into a range of 1 to 5 where a market with a score 1 is a highly transparent real estate market, whilst a score of 5 represents the market transparency level is opaque. In other words, a lower GRETI scored property market suggests that it is a transparent market.
Even though it is a transparency index for real estate, the index covers a number of broader aspects such as market fundamentals, governance, regulatory and legal, performance, transaction process and sustainability (Jones Lang LaSalle [JLL], 2018). In other words, the index not only captures real estate aspects, but also the broader aspects. Importantly, the index has been widely used by real estate studies in gauging the institutional quality of a country (Farzanegan \& Fereidouni, 2014; Newell, 2016). Therefore, we employed this index in measuring the institutional quality of a country. Although the Chinese property market has recorded some improvement in its transparency in recent years, it is still characterised as a semi-transparent property market. As discussed earlier, Chinese investors have prior knowledge of the complex operation of real estate investment in an emerging market without high transparency. As posited by Alexsynska and Havrylchnyk (2013), investors from emerging economies (e.g. China) would prefer countries with the highest institutional quality if they invest in developed economies with better institutions, no similar preference is required if they invest in emerging economies. Thus, we expect that transparency scores could have an asymmetric impact on the Chinese outward FDIRE. Specifically, transparency has an impact on foreign real estate investment via an interaction term with market size and/or the host country development speed level, particularly transparency has a higher impact on Chinese outward FDIRE in larger economies (highly growth markets), whilst its impact would be less critical in smaller markets (slowly growth markets). 


\section{Real estate market-specific factors}

Several real estate market-specific factors have also been considered as controlled variables. Firstly, property prices of a host country are considered. Previous real estate studies found that heightening property prices ${ }^{7}$ would attract foreign capital flow into real estate (Zhu et al., 2006; He et al., 2009; Farzanegan \& Fereidouni, 2014; Hui \& Chan, 2014). Nevertheless, a long-term co-integration study of Rodriguez and Bustillo (2010) found a negative link between expectations of heightening property prices and foreign investment in the Spanish property market. Overall, it is hypothesised that price would have a positive impact on Chinese outward FDIRE. In this study, we utilize housing price growth rate and expect the markets with higher housing price growth will attract more investment.

Given debt financing is commonly used for property investment, borrowing costs are expected to have some impact on FDIRE, particularly for foreign real estate investors who rely on the financial systems in the host countries to raise investment capital (Ramasamy \& Yeung, 2010). In this study, interest rate has been used as a proxy for financing or borrowing costs. The empirical evidence in the literature has also suggested that the increase of interest rate will lead to higher borrowing costs, which in turn might hinder foreign investment, although the significant levels vary different studies (He et al., 2009; Rodriguez \& Bustillo, 2010; Farzanegan \& Fereidouni, 2014; Hui \& Chan, 2014). Therefore, this study expects that there is a negative link between financing costs in the host countries and the flow of FDI in real estate.

Population growth is also introduced into the model as a control variable in respect to high population growth leads to high housing demand and higher housing prices (Stevenson, 2008; Al-Masum \& Lee, 2019). In other words, population growth reflects market fundamentals; thereby markets with a higher population growth rate could attract more foreign investment in real estate, including Chinese foreign investment.
Lastly, GDP per capita growth rate is another control variable. It measures how the development level of a host market can partly explain FDI flow. In this study, we further expect that countries with higher GDP growth rate have larger real estate investment opportunities. Therefore, we expect that Chinese investors would prefer to invest in markets that have higher GDP per capita growth rate. Following the study of Buckley et al. (2007), REFDI, GDP and distance are taken in logarithmic form as nonlinearity is expected in the relationships between outward FDIRE and the explanatory variables. This also eliminates potential scaling problem. Summary statistics are reported in Table 2.

\subsection{Empirical specifications}

\section{Baseline model}

To assess the determinants of Chinese outward FDIRE, especially the role of institution factor in the FDI decision, a panel data analysis is adopted. It is examined by regressing the Chinese international real estate investment with a set of explanatory variables, including gravity-related factors, institutional factor and real estate specific variables in a panel form. We take the following panel data regression model as our baseline model:

$$
\begin{aligned}
& \text { REFDI }_{i, t}=\beta_{0}+\beta_{1} \text { GDP }_{i, t}+\beta_{2} \text { Dist }_{i}+\beta_{3} \text { Lang }_{i}+ \\
& \beta_{4} \text { RETrans }_{i, t}+\beta_{5} \operatorname{GDPP}_{i, t}+\beta_{6} H P_{i, t}+\beta_{7} I_{i, t}+ \\
& \beta_{8} \text { Pop }_{i, t}+\sum_{i=2007}^{2016} \gamma_{i} \text { year }_{i}+\varepsilon_{i, t},
\end{aligned}
$$

where: $R E F D I_{i, t}$ represents real estate FDI from China to the recipient country $i$ in year $t$; GDP $i, t$ is total GDP of recipient country $i$ in year $t$; Dist $t_{i}$ is geographic distance of recipient country $i$ to Beijing (China); Lang $g_{i}$ denotes a dummy variable in which 1 represents the host country $i$ has Chinese as one of its official languages; RETrans $s_{i, t}$

Table 2. Descriptive statistics

\begin{tabular}{|l|c|c|c|c|c|}
\hline \multicolumn{1}{|c|}{ Variable } & Observations & Mean & Std. Dev. & Min & Max \\
\hline REFDI (US\$ million) & 450 & 1.649 & 2.623 & 0.000 & 9.996 \\
\hline GDP (US\$ billion) & 450 & 26.541 & 1.873 & 19.027 & 30.556 \\
\hline Distance (km) & 450 & 8.753 & 0.584 & 6.862 & 9.738 \\
\hline Language & 450 & 0.111 & 0.315 & 0.000 & 1.000 \\
\hline Real estate transparency (RETrans) & 393 & 2.251 & 0.747 & 1.150 & 4.460 \\
\hline GDP per capita growth rate (\%) & 450 & 1.342 & 4.090 & -23.125 & 23.957 \\
\hline Housing price (\%) & 349 & 0.032 & 0.071 & -0.194 & 0.271 \\
\hline Interest (\%) & 325 & 3.003 & 3.621 & -0.750 & 21.875 \\
\hline Population (\%) & 449 & 0.997 & 1.351 & -1.854 & 14.237 \\
\hline
\end{tabular}

Note: REFDI, GDP and distance are presented in logarithm.

7 Housing is also one of the largest asset for many Chinese households (Weng \& Gong, 2017; Tang, Ye, \& Qian, 2019). 
denotes real estate transparency score; GDPp $p_{i, t}$ denotes GDP per capita growth rate; $H P_{i, t}$ represents housing price growth rate; $I_{i, t}$ is interest rate and $p o p_{i, t}$ is the population growth rate of recipient country $i$ in year $t$. To consider market shocks such as the global financial crisis (GFC) in 2008 and China's varying outward FDI policies in recent years, a year dummy year $r_{i}(\boldsymbol{i}=2007, \ldots$ 2016) is introduced in order to capture the year-specific effects over the sample period (Lee, Stevenson, \& Lee, 2018).

\section{Asymmetric effects of institutional quality}

Given we have hypothesised an asymmetric effect of institutional quality on China's outward FDIRE, we also introduce two interaction terms of real estate market transparency and (1) market size (real GDP) and (2) economic development level (measured by GDP per capita growth). We conjecture that transparency levels of large economies and economies with rapid growth rates are crucial factors in explaining Chinese investors' decision making as these economies have more property investment opportunities. Specifically, real estate investment opportunities in a transparent property market could be more efficiently identified. However, it is less critical for smaller economies and economies with low growth rates. The augmented models are set in Equation (4). The purpose is to shed more lights into how the transparency level of a host property market affects Chinese investors' decision concerning FDIRE. The augmented model with an interaction term of real estate transparency and GDP and GDP per capita growth can be presented as follows:

$$
\begin{aligned}
& \text { REFDI }_{i, t}=\beta_{0}+\beta_{1} \text { GDP }_{i, t}+\beta_{2} \text { Dist }_{i}+\beta_{3} \text { Lang }_{i}+ \\
& \beta_{4} \text { RETrans }_{i, t}+\beta_{5} \text { GDPP }_{i, t}+\beta_{6} \text { HP P }_{i, t}+\beta_{7} I_{i, t}+ \\
& \beta_{8} \text { pop }_{i, t}+\beta_{9} \text { RETrans }_{i, t} \cdot \text { Eco }_{i, t}+\sum_{i=2007}^{2016} \gamma_{i} \text { year }_{i}+\varepsilon_{i, t},
\end{aligned}
$$

where: Eco in the interaction term represents economic factors (either GDP or GDP per capita growth). The estimation results are exhibited in the following section.

\section{Empirical results and discussion}

\subsection{Results of baseline model}

The empirical results of Equation (3) are reported in Table 3. Three empirical models have been undertaken in which Model I is a basic model, which examines the extent to which gravity-related factors and the institutional factor explain Chinese outward FDIRE. In Model II, the cultural proximity has been considered, whilst the property specific factors are introduced in Model III as controlled variables ${ }^{8}$.

\footnotetext{
8 Both fixed effect (FE) and random effect (RE) specifications have been estimated. The results of Hausman test suggest that coefficients of the estimated FE and RE estimators do not differ in a systematic way and the RE estimators are consistent and efficient. Therefore, we present the results of RE estimation which produces more reliable results.
}

Table 3. Determinants of Chinese outward FDIRE: panel estimation

\begin{tabular}{|l|c|c|c|}
\hline \multirow{2}{*}{ Independent variables } & \multicolumn{3}{|c|}{$\begin{array}{c}\text { Dependent variable: } \\
\text { outward FDIRE }\end{array}$} \\
\cline { 2 - 4 } & Model I & Model II & Model III \\
\hline GDP & $\begin{array}{c}0.503 \\
(0.168)^{* * *}\end{array}$ & $\begin{array}{c}0.696 \\
(0.156)^{* * *}\end{array}$ & $\begin{array}{c}0.710 \\
(0.169)^{* * *}\end{array}$ \\
\hline Distance & -0.963 & -0.137 & -0.546 \\
& $(0.349)^{* * *}$ & $(0.373)$ & $(0.379)$ \\
\hline Real estate transparency \\
(RETrans) & -0.711 & -0.538 & -1.462 \\
$(0.286)^{* * *}$ & $(0.267)^{* *}$ & $(0.332)^{* * *}$ \\
\hline Language & & 2.712 & 2.265 \\
& & $(0.687)^{* * *}$ & $(0.744)^{* * *}$ \\
\hline GDP per capita growth & & & 0.183 \\
rate & & & $(0.082)^{* *}$ \\
\hline Housing price & & & 2.015 \\
& & & $(2.661)$ \\
\hline Interest & & & -0.005 \\
& & & -0.172 \\
\hline Population & & & $(0.270)$ \\
\hline Constant & -2.617 & -15.761 & -11.1384 \\
& $(5.983)$ & $(6.382)^{* * *}$ & $(6.640)^{*}$ \\
\hline Year effects & Included & Included & Included \\
\hline Adjusted R square & 0.321 & 0.38 & 0.478 \\
\hline
\end{tabular}

Notes: Robust standard errors (S.E.) in parentheses. ${ }^{* *} \mathrm{p}<0.01,{ }^{* *} \mathrm{p}<0.05$, ${ }^{*} \mathrm{p}<0.1$.

As hypothesised, the coefficient of GDP is positive and statistically significant at $1 \%$ level in Models I-III, reflecting that Chinese investors have a tendency to invest in larger economies. Specifically, a 1\% rise in recipient country's GDP will lead to an increase of Chinese outward FDIRE by nearly $0.7 \%$. Given that market size reflects availability of investment possibilities, it is reasonable to expect that Chinese real estate investors preferentially invest in larger economies with more property investment opportunities. This is consistent with the results of Buckley et al. (2007) based on the aggregated outward FDI from China. It also offers some support to the market-seeking hypothesis in which market seeking was a key motive for Chinese outward FDIRE over this study period.

Another noteworthy finding is that the coefficient of geographic distance is negative but not significant with the introduction of cultural proximity. It is contrary to the general findings for the gravity model that distance has a significant impact on trans-boundary flow of goods and inputs (Buckley et al., 2007; Blomkvist \& Drogendijk, 2013). The interpretation of this finding is that, unlike FDI in other sectors such as manufacturing, international real estate investment does not lead to any flow of goods. Therefore, Chinese real estate investors are less sensitive to geographic distance compared with multi-national enterprises. Indeed, geographical diversification strategy has been seen as a key diversification strategy (Byrne \& Lee, 2009). This also confirms the assertion that the determinants put forward by the mainstream international 
business literature is not applicable to FDIRE in response to the unique features of real estate. The documented results here also highlight the presence of sector differences and the importance of a dedicated study of FDIRE as real estate is a unique sector.

Cultural proximity appears to have a positive and significant impact on Chinese outward FDIRE. The result suggests that Chinese international real estate investment reacts positively to the level of cultural proximity in the host market. Specifically, this variable reflects that Chinese property investors prefer host markets that are culturally similar to China. This indicates that markets with Chinese as one of their official languages would attract more real estate investment from China. It also suggests that real estate investment from China can be enhanced with the presence of ethnic Chinese in the host market. Comparable results are found from Models II and III. The results also support the view of Zhan (1995) and Erdener and Shapiro (2005) that strong ties among overseas Chinese have assisted Chinese investors to overcome the possible cultural barriers and identify property investment opportunities in foreign markets more effectively.

As hypothesised, the coefficient of RETrans is negative and statistically significant at 5\% level in Models I-III, suggesting that real estate transparency, an institutional factor, does have an acute impact on China's FDIRE. Specifically, Chinese investors would prefer to invest in markets with higher transparency levels (a market with a lower JLL RETrans score represents the market have a higher level of market transparency and market institution quality). The results are consistent with the argument of Adair, Allen, Berry, and McGreal (2006) in which an increased real estate transparency would reduce the information asymmetry problem in real estate investment; thereby transparent property markets would be more appealing to foreign real estate investors. Specifically, Chinese real estate investors can be better informed of the institutional structure and business practices of transparent property markets; thereby their investment confidence can be enhanced in these markets.

In Model III, the robustness of gravity-related variables and institutional variable are further investigated by introducing property related explanatory variables as control variables. The significant and positive coefficient for GDP per capita growth rate suggests that Chinese intend to invest in the fast-growing market. The results are in line with the market growth hypothesis of Buckley et al. (2007) in that Chinese foreign investments are largely towards rapidly growing economies. Specifically, these markets present more opportunities for generating profits. Thus, one would expect investors may keen to invest more in host markets with a high economic growth rate. Nevertheless, the insignificant and positive coefficient of housing price growth rate in Model III suggests that heightening property prices in a market do lead to higher Chinese real estate investment of that market, but is not to statistically significant extent. This implies that past performance of a market does not seem to be such a relevant variable or a sole consideration for Chinese real estate investors' investment decision making. In addition, the sign of interest rate is the expected one, but it is not statistically significant. Comparable results are documented by Hui and Chan (2014) for Chinese inward FDIRE. The results can be attributed to the unique institutional and legal context of Chinese real estate investment. As discussed by Chen (2004), Chinese investors are less likely to rely on debt financing in their property acquisitions as Chinese investors prefer equity financing to debt financing. Lastly, an insignificant coefficient of population growth is evident, indicating that high population growth rate does not necessarily lead to higher FDIRE from China. It also implies that Chinese investors might not view this as a good indicator to represent property demand.

Overall, the existing gravity model (e.g. GDP and cultural proximity) does explain the pattern of Chinese overseas real estate investment, whilst this theory might not fully explain Chinese outward FDIRE in the light of some variables (such as geographic distance) are not very relevant in understanding the real estate sector due to the special nature of real estate investment. Importantly, institutional factor, namely real estate transparency appears as one of the critical explanatory variables of Chinese cross-border real estate investment. This highlights the importance of an extended institutional-gravity model in explaining Chinese real estate investment abroad.

\subsection{Dynamic panel model}

The preceding section shows that the impact of institution factor on China's outward real estate FDI has been evaluated by means of panel data regressions. However, it can be argued that estimated panel models are subject to a potential endogeneity problem. As discussed earlier, institutional quality of a real estate market, which is one of the determinants of China's investment, could be partly determined by other variables. To shed more light on the robustness of estimated results and adjusting for the potential endogeneity, the relationship between institution and China's outward REFDI is re-evaluated by means of a dynamic panel data (DPD) approach. In this section, a Generalized Method of Moment (GMM) model is utilised as an alternative estimation to disentangle the problem of endogeneity (Bi, Fan, Gao, Lee, \& Yin, 2019). Specifically, a system GMM estimation is utilised in which real estate transparency is assumed to be possible endogenous. In addition, real estate transparency is used as a GMM instrument and the difference terms of other covariates are used as standard instruments for the first difference equation. The results for system GMM estimation are reported in Table 4. 
Table 4. Determinants of Chinese outward FDIRE: system GMM estimation

\begin{tabular}{|c|c|}
\hline Independent variables & Coefficient \\
\hline GDP & $\begin{array}{c}0.889 \\
(0.208)^{* * *}\end{array}$ \\
\hline Distance & $\begin{array}{c}-1.412 \\
(0.538)^{\star * *}\end{array}$ \\
\hline $\begin{array}{l}\text { Real estate transparency } \\
\text { (RETrans) }\end{array}$ & $\begin{array}{c}-5.217 \\
(1.041)^{* * *}\end{array}$ \\
\hline Language & $\begin{array}{c}1.489 \\
(0.865)^{\star}\end{array}$ \\
\hline GDP per capita growth rate & $\begin{array}{c}0.261 \\
(0.181) \\
\end{array}$ \\
\hline Housing price & $\begin{array}{c}2.507 \\
(2.898) \\
\end{array}$ \\
\hline Interest & $\begin{array}{c}0.096 \\
(0.035)^{* * *}\end{array}$ \\
\hline Population & $\begin{array}{l}-0.191 \\
(0.584)\end{array}$ \\
\hline Year effect & Included \\
\hline $\begin{array}{l}\mathrm{AB} \text { test for } \mathrm{AR}(1) \text { in first } \\
\text { differences }\end{array}$ & $\mathrm{z}=-2.45$ Prob $>\mathrm{z}=0.014$ \\
\hline $\begin{array}{l}\mathrm{AB} \text { test for } \mathrm{AR}(2) \text { in first } \\
\text { differences }\end{array}$ & $z=-0.91$ Prob $>z=0.363$ \\
\hline $\begin{array}{l}\text { Sargan test of override } \\
\text { restrictions }\end{array}$ & $\begin{array}{l}\text { Chi-square }(25)=176.50 \\
\text { Prob }>\text { chi-square }=0.000\end{array}$ \\
\hline
\end{tabular}

Notes: Robust standard errors (S.E.) in parentheses. ${ }^{* *} \mathrm{p}<0.01,{ }^{* *} \mathrm{p}<0.05$, ${ }^{*} \mathrm{p}<0.1$.

Table 4 presents the estimated results from the system GMM. In general, the GMM results are fairly consistent with the results from the preceding panel regression. In other words, the conclusion from the panel regression is robust. Specifically, the results of Table 4 shows that GDP has a positive and significant impact, which is consistent with the theoretical assertion of the gravity model. Besides, the positive coefficient of common language confirms the importance of cultural proximity in explaining Chinese outward real estate investment. The negative coefficient of real estate transparency indicates that lower real estate transparency index of home country (i.e., higher institutional quality) will lead to more FDI from China. In short, the results suggest that the baseline results are robust. The only exception is geographic distance in which it has a significant and negative impact on FDIRE ${ }^{9}$. In brief, our GMM results suggest that the baseline results are fairly robust after adjusting for the potential endogeneity. Specifically, both gravity-related factors and institutional factors are critical in explaining Chinese FDIRE.

\footnotetext{
9 The Sargan test for over-identifying restrictions is used to test whether or not the GMM model specification is appropriate. The null hypothesis of the Sargan test is that over-identifying restrictions are valid (i.e., the instruments are exogenous and not related to the error term). The Sargan test focuses on the robustness of estimation and weakness of instruments respectively. The result shows that GMM results could be accepted by the Sargan test, reflecting that the instruments used in the model are exogenous, that is, the over-identifying restrictions are valid.
}

\subsection{Asymmetric impact of institutional quality}

Although the baseline results suggest that an enhancement of institutional quality would increase China's outward FDI in the host country, the quality of institutions could have an asymmetric effect on the abovementioned link given Chinese investors' prior knowledge of real estate operations in emerging markets. To assess the asymmetric hypothesis, we introduce the interaction terms of real estate market transparency and (1) market size (real GDP) and (2) economic development level (measured by GDP per capita growth) as specified by Equation (4). The estimated results for the specifications with interaction terms are reported by Table 5 .

Model I shows the estimated results of the model which includes an interaction between real estate market transparency and GDP. The rationale is that the institutional factor may have different effects for countries with different economic mass. More specifically, it is hypothesised that transparency scores are only significant to attract more Chinese FDIRE in larger economies. As can be seen in Table 5, the interaction term of transparency and GDP is negative and significant significantly, reflecting that transparency does have an impact on Chinese outward FDIRE, whilst the impact of transparency index is not constant. Indeed, real estate transparency has an

Table 5. Asymmetric effect of institutional quality

\begin{tabular}{|c|c|c|}
\hline \multirow{2}{*}{ Independent variables } & \multicolumn{2}{|c|}{$\begin{array}{l}\text { Dependent variable: } \\
\text { outward REFDI }\end{array}$} \\
\hline & Model I & Model II \\
\hline GDP & $\begin{array}{c}1.877 \\
(0.483)^{* * *}\end{array}$ & $\begin{array}{c}0.733 \\
(0.137)^{\star * *}\end{array}$ \\
\hline Distance & $\begin{array}{c}-0.804 \\
(-0.804)^{\star *}\end{array}$ & $\begin{array}{c}-0.762 \\
(-0.308)^{\star * *}\end{array}$ \\
\hline $\begin{array}{l}\text { Real estate transparency } \\
\text { (RETrans) }\end{array}$ & $\begin{array}{c}14.598 \\
(6.240)^{\star \star}\end{array}$ & $\begin{array}{c}-1.560 \\
(-0.296)^{* * *}\end{array}$ \\
\hline Language & $\begin{array}{c}1.987 \\
(0.768)^{\star * *}\end{array}$ & $\begin{array}{c}1.809 \\
(0.611)^{\star \star *}\end{array}$ \\
\hline GDP*RETrans & $\begin{array}{c}-0.591 \\
(-0.230)^{\star * *}\end{array}$ & \\
\hline $\begin{array}{l}\text { GDP per } \\
\text { capita*RETrans }\end{array}$ & & $\begin{array}{c}-0.190 \\
(-0.090)^{\star \star}\end{array}$ \\
\hline GDP per capita & $\begin{array}{c}0.220 \\
(0.082)^{* * *}\end{array}$ & $\begin{array}{c}0.686 \\
(0.250)^{* * *}\end{array}$ \\
\hline Housing price & $\begin{array}{l}1.876 \\
(2.265)\end{array}$ & $\begin{array}{c}0.983 \\
(2.727)\end{array}$ \\
\hline Interest & $\begin{array}{c}0.016 \\
(0.034)\end{array}$ & $\begin{array}{c}0.011 \\
(0.028)\end{array}$ \\
\hline Population & $\begin{array}{l}-0.031 \\
(-0.277)\end{array}$ & $\begin{array}{l}-0.060 \\
(-0.240)\end{array}$ \\
\hline Constant & $\begin{array}{c}-40.956 \\
(-13.246)^{\star * *}\end{array}$ & $\begin{array}{c}-9.916 \\
(-5.426)^{*}\end{array}$ \\
\hline Year effects & Included & Included \\
\hline Adjusted R square & 0.497 & 0.492 \\
\hline
\end{tabular}

Notes: Robust standard errors (S.E.) in parentheses. ${ }^{* *} \mathrm{p}<0.01,{ }^{* *} \mathrm{p}<0.05$, ${ }^{\star} \mathrm{p}<0.1$. 
impact on foreign real estate investment via an interaction term with market size. As discussed earlier, larger markets indicate more investment opportunities. A transparent property market, which is characterised by a lower transparency index, in a larger economy is critical to assist Chinese investors in identifying investment possibilities. This factor is, however, less critical in small economies.

Furthermore, the F-test of the joint hypothesis that real estate transparency and the interaction effect (GDP*RETrans) jointly have an impact on FDIRE, confirming the importance of institutional factor in explaining the Chinese outward FDIRE is conditional on GDP. Based on the estimated coefficients of GDP and transparency in Table 5, we can further gauge the marginal impact of transparency on Chinese outward FDIRE based on the following equation:

$$
\frac{d\left(\text { REFDI }_{i, t}\right)}{d\left(\text { RETrans }_{i, t}\right)}=14.598-0.591 \cdot \text { mean } \cdot G D P=-1.088
$$

It is important to note that the estimated coefficient of the interaction term is -0.591 . It measures the effect of institutional quality (i.e. transparency) when the GDP is equal to zero. To gauge the marginal impact of transparency on Chinese outward FDIRE, the mean log value of GDP of $\$ 26.541$ billion is used. Therefore, at the mean value of GDP, the impact of RETrans on FDIRE is -1.088, indicating that a $1 \%$ improvement on transparency score (or a drop of the transparency index, which reflects a greater level of transparency) will lead to a greater $1.088 \%$ Chinese real estate investment in a country with an average market size of $\$ 26.5$ billion (in log).

Similarly, Model II of Table 5 shows the estimated results of the model which includes an interaction between real estate market transparency and GDP per capital growth rate. It assesses whether institutional quality may have different effects for countries with different economic growth rates. The estimated coefficient of the interaction term is -0.19 . It measures the effect of institutional quality on FDIRE when the GDP per capita growth is equal to zero. Given the mean value of GDP per capita growth is $1.342 \%$, the marginal impact of real estate transparency, at the mean value of GDP per capita, on FDIRE can be estimated as follows:

$$
\frac{d\left(\text { REFDI }_{i, t}\right)}{d\left(\text { RETrans }_{i, t}\right)}=-1.56-0.19 \cdot \text { mean }(\text { GDPp })=-1.815
$$

This suggests that a $1 \%$ improvement on transparency score (or a drop of the transparency index, which reflects a greater level of transparency) will lead to a greater $1.815 \%$ Chinese real estate investment in a market with a GDP per capita growth rate of $1.34 \%$. In short, markets with low JLL real estate market transparency index (or high institutional quality) lead to higher investment from China, whilst this is conditional on the speed of economic growth of and the size of the market.

To assess the economic significance of the marginal effects, we further test whether the estimated effects are
Table 6. Asymmetric effect of institutional quality at

\begin{tabular}{|c|c|c|}
\hline \multirow{2}{*}{ Independent variables } & \multicolumn{2}{|c|}{ Dependent variable: outward REFDI } \\
\hline & Model I & Model II \\
\hline GDP & $\begin{array}{l}1.877 \\
(0.483)^{\star * *}\end{array}$ & $\begin{array}{l}0.733 \\
(0.137) * * *\end{array}$ \\
\hline Distance & $\begin{array}{l}-0.804 \\
(-0.804)^{\star \star} \\
\end{array}$ & $\begin{array}{l}-0.762 \\
(-0.308)\end{array}$ \\
\hline $\begin{array}{l}\text { Real estate } \\
\text { transparency (RETrans) }\end{array}$ & $\begin{array}{l}-1.095 \\
(-0.359)^{\star * *}\end{array}$ & $\begin{array}{l}-1.814 \\
(-0.277)^{\star * *}\end{array}$ \\
\hline Language & $\begin{array}{l}1.987 \\
(0.768)^{\star * *}\end{array}$ & $\begin{array}{l}1.809 \\
(0.611) * * *\end{array}$ \\
\hline $\begin{array}{l}\text { (GDP of } \\
26.541)^{\star} \text { RETrans }\end{array}$ & $\begin{array}{l}-0.591 \\
(-0.230)^{\star * *}\end{array}$ & \\
\hline $\begin{array}{l}\text { (GDP per capita of } \\
1.342)^{\star} \text { RETrans }\end{array}$ & & $\begin{array}{l}-0.190 \\
(-0.090)\end{array}$ \\
\hline GDP per capita & $\begin{array}{l}0.220 \\
(0.082)^{* * *}\end{array}$ & $\begin{array}{l}0.686 \\
(-0.250) \text { *** }\end{array}$ \\
\hline Housing price & $\begin{array}{l}1.876 \\
(2.265)\end{array}$ & $\begin{array}{l}0.983 \\
(2.727)\end{array}$ \\
\hline Interest & $\begin{array}{l}0.016 \\
(0.034) \\
\end{array}$ & $\begin{array}{l}0.011 \\
(0.028) \\
\end{array}$ \\
\hline Population & $\begin{array}{l}-0.031 \\
(-0.277)\end{array}$ & $\begin{array}{l}-0.060 \\
(-0.240)\end{array}$ \\
\hline Constant & $\begin{array}{l}-40.956 \\
(-13.246)^{* * *}\end{array}$ & $\begin{array}{l}-9.916 \\
(-5.426)\end{array}$ \\
\hline Year effects & Included & Included \\
\hline Adjusted R square & 0.497 & 0.492 \\
\hline
\end{tabular}
an average level

Notes: Robust standard errors (S.E.) in parentheses. ${ }^{* *} \mathrm{p}<0.01$, ${ }^{* *} \mathrm{p}<0.05$, ${ }^{*} \mathrm{p}<0.1$.

statistically different from zero. To do so, we rerun the regressions by replacing the interaction term between GDP and real estate transparency with a new interaction term. The new interaction term is the interaction term between GDP of $\$ 26.541$ billion and real estate transparency, which represents the estimated effect at the mean value of GDP. The second interaction term is the interaction term between GDP per capita growth of $1.342 \%$ and real estate transparency. This exhibits the estimated effect at the mean value of GDP per capita growth. The results are reported in Table 6.

As expected, the coefficient of RETrans of Model I Table 6 is -1.095. It indicates the partial effect of institutional factor on FDIRE at the mean value of $\mathrm{GDP}^{10}$. The results show that, on the average level, lower score of real estate transparency (i.e., higher institutional quality) leads to higher investment from China into recipient country's market. The negative coefficient of transparency in Table 6 shows that transparency does have an impact on Chinese outward FDIRE, whilst the impact of transparency index

\footnotetext{
10 Theoretically, the estimated coefficient of RETrans at the average level (-1.095) should be equal to the marginal effect of -1.088 that was estimated by Equation (3). The marginal difference can be attributed to the use of decimal.
} 
on Chinese outward FDIRE is not constant. Indeed, institutional quality (i.e. real estate transparency) has an impact on foreign real estate investment via an interaction term with the market size of a host country; particularly transparency has a higher impact on Chinese outward real estate investment in larger markets and the asymmetric effect is statistically significant. In other words, the marginal impact of transparency on the Chinese outward FDIRE is asymmetrically influenced by market size. Comparable evidence is documented in Model II of Table 6 in respect to the coefficient of RETrans is negative and statistically significant. Again this confirms that markets with low real estate market transparency index (or high institutional quality) lead to higher investment from China, whilst this is conditional on the speed of economic growth of the market. Importantly, the asymmetric effects are statistically significant.

To sum up, the interaction term analyses suggest the asymmetric effect of institutional quality (i.e. real estate transparency) on Chinese outward FDI. Specifically, Chinese investors prefer transparent real estate markets, whilst the marginal effect of transparency or institutional quality is not constant. Specifically, transparent property markets would attract higher investment from China, whilst there is conditional on the market size and the speed of economic growth of a country.

\subsection{Robustness checks}

To enhance the robustness of our empirical results, we exclude tax havens, including Hong Kong, Palau, the Bahamas and the United Arab Emirates, from the sample countries and re-estimate the Equation (4). PWC report was used to identify tax havens in which it provides a list of countries, territories and regions that provide a favourable tax regime (PricewaterhouseCoopers, 2017). The results are very consistent with the results in Table 5. We found that transparency does have an impact on FDIRE. However, the impact is not constant in which transparent property markets' ability to attract higher investment from China is conditional on the market size and the speed of economic growth of a country. The positive and significant coefficient of cultural proximity further reinforces the view that cultural proximity between the host markets and China is important in the flow of Chinese outward FDIRE as Chinese real estate investors prefer real estate markets that are culturally similar to China. Lastly, unlike the empirical results from the gravity model in Table 5, geographic distance does not have a strong impact on FDIRE. Again the results are in line with our baseline results, reflecting the unique nature of international real estate investment compared with other sectors. Insignificant results are also documented for housing price, population and interest rate. To sum up, the results here confirm the previous findings in which Chinese outward FDIRE is driven by market size (GDP), cultural proximity and the institutional quality of the host markets (i.e. property market transparency) via an interaction term with the market size or speed of economy growth (either GDP or GDP growth rate) of the host countries. This also suggests our baseline results are robust to the exclusion of tax haven countries from our sample.

We also added a number of control variables. Importantly, previous studies on FDI have found that these control variables to be of importance in explaining global FDI flows. These control variables are openness, exchange rates and inflation rate. When adding these control variables, although openness appears as another key driver of Chinese real estate investment abroad, our results are qualitatively similar to the baseline results ${ }^{11}$. Importantly, we found that Chinese real estate investors prefer larger host economies coupled with highly transparent real estate markets, as well as host markets where cultural proximity to China. In other words, our results are robust to the inclusion of these control variables.

\section{Conclusions and policy implications}

This study is the first attempt to assess the asymmetric impact of institutional quality on Chinese outward FDIRE using an extended gravity model with a real estate institutional factor (namely real estate transparency). Specifically, this is the first sectoral study to examine the determinants of Chinese outward FDIRE by considering institutional asymmetry. Using the unique dataset from Real Capital Analytics and a range of mainstream explanatory and property specific variables over 2007-2016, we have identified the determinants of Chinese outward FDIRE for the first time.

Several findings have been identified from this study. Firstly, a number of tests indicate that real estate transparency, which is a real estate institutional quality factor, is a key factor in explaining China's outward FDIRE in larger and fast developing economies. Specifically, transparency has an impact on Chinese foreign real estate investment, whilst it is conditional on the market size and the speed of economic growth of a country. This highlights the asymmetric effect of institutional quality on Chinese outward FDI. This can be attributed to their prior knowledge of operations in an emerging real estate market. This also suggests that institutional asymmetry as well as the general theory are required in understanding China's outward FDIRE. Secondly, the gravity theory itself cannot fully explain Chinese outward investing behaviour in the real estate sector. In fact, both the established gravity model and real estate institutional factor together explain Chinese outward FDIRE. This also highlights the presence of sectoral differences and a dedicated study of the outward FDIRE is paramount as real estate is a unique sector. Thirdly, cultural proximity emerges as an important factor, suggesting that Chinese investors seek foreign real estate investment opportunities in environment that they

\footnotetext{
${ }^{11}$ Results are not reported for brevity.
} 
are familiar with. This again confirms the importance of cultural proximity in explaining the Chinese outward FDI.

There are some far reaching policy implications from this research. First, the findings suggest the importance of a sectoral study in response to a sectoral effect has been documented. This also leads to a question of the appropriateness of a uniform FDI policy for all sectors. Consequently, policy makers should consider the divergences between different sectors in formulating their FDI policies. Second, policy makers and investors should acknowledge the fact that FDIRE cannot be fully explained by the general theory of FDI. To provide a rigorous foundation for policy formulation, they should expand the general theory with considering the institutional quality factor as the general theory might not be directly generalized into the property sector. Lastly, policy makers and property practitioners, particularly in larger economies and countries with rapid growth should enhance the real estate transparency levels (higher institutional quality) of their countries in respect to larger and rapidly growth economies with a transparent property market (asymmetry impact) will likely to stimulate foreign real estate investment from China.

With respect to further work, although this study has formally examined the driving forces of Chinese outward FDIRE, outward FDIRE from other markets merit further investigation. Given China's FDI is very sensitive to the policies of the Chinese government, we would like to qualify our findings to the continuation of the relevant policies (e.g. 'One belt, one road' initiative). If there is a change in the relevant policies, a future study of Chinese outward FDIRE is necessary. In addition, the impact of the recent changes of the host country's regulatory environment and the host market's lifestyle on the Chinese outward FDIRE (e.g. Canada's change in regulation of foreign investment) warrants further studies.

\section{Acknowledgements}

Chyi Lin Lee would like to thank the data access provided by Steve Williams from Real Capital Analytics. The unique dataset from Real Capital Analytics allows us to assess the Chinese OFDI into a particular sector for the first time. The constructive comments from the editor and two referees are really appreciated.

\section{Author contributions}

Jingjing Zhang and Chyi Lin Lee contributed equally to this paper. Both of them were responsible for the development of the study. Jingjing Zhang was responsible for data analysis, whilst Chyi Lin Lee was responsible for the design of the analysis and writing of the article. Nelson Chan was responsible for the policy analysis.

\section{Disclosure statement}

No potential conflict of interest was reported by the authors.

\section{References}

Adair, A., Allen, S., Berry, J., \& McGreal, S. (2006). Central and Eastern European property investment markets: issues of data and transparency. Journal of Property Investment and Finance, 24(3), 211-220. https://doi.org/10.1108/14635780610659928

Alexsynska, M., \& Havrylchnyk, O. (2013). FDI from the South: the role of institutional distance and natural resources. European Journal of Political Economy, 29, 38-53.

https://doi.org/10.1016/j.ejpoleco.2012.09.001

Al-Masum, A., \& Lee, C. L. (2019). Modelling housing prices and market fundamentals: evidence from the Sydney housing market. International Journal of Housing Markets and Analysis. https://doi.org/10.1108/IJHMA-10-2018-0082

Anderson, J. E. (2011). The gravity model. Annual Review of Economics, 3, 133-160.

https://doi.org/10.1146/annurev-economics-111809-125114

Anderson, J. E., \& Wincoop, E. V. (2004). Trade costs. Journal of Economic Literature, 42(3), 691-751. https://doi.org/10.1257/0022051042177649

Bi, L., Fan, Y., Gao, M., Lee, C. L., \& Yin, G. (2019). Spatial mismatch, enclave effects and employment outcomes for rural migrant workers: empirical evidence from Yunnan Province, China. Habitat International, 86, 48-60.

https://doi.org/10.1016/j.habitatint.2019.02.008

Blomkvist, K., \& Drogendijk, R. (2013). The impact of psychic distance on Chinese outward foreign direct investments. Management International Review, 53, 659-686. https://doi.org/10.1007/s11575-012-0147-y

Buckley, P. J., Clegg, L. J., Cross, A. R., Liu, X., Voss, H., \& Xheng, P. (2007). The determinants of Chinese outward foreign direct investment. Journal of International Business Studies, 38, 499518. https://doi.org/10.1057/palgrave.jibs. 8400277

Byrne, P., \& Lee, S. (2009). Spatial concentration in institutional investment in the UK: some comparisons between the retail and office sectors. Journal of Property Investment and Finance, 27(1), 5-24. https://doi.org/10.1108/14635780910926649

Cushman \& Wakefield. (2018). Chinese capital flows: where to from here? (pp. 1-16). Sydney, Cushman \& Wakefield.

CBRE (2015). The expanding role of Chinese capital in global real estate markets (pp. 1-21). CBRE.

Chen, J. J. (2004). Determinants of capital structure of Chineselisted companies. Journal of Business Research, 57, 1341-1351. https://doi.org/10.1016/S0148-2963(03)00070-5

Chin, W., Dent, P., \& Roberts, C. (2006). An exploratory analysis of barriers to investment and market maturity in Southeast Asian cities. Journal of Real Estate Portfolio Management, 12(1), 49-57.

Deng, K. K., Wong, S. K., \& Chau, K. W. (2018). Institutions and capital structure: the case of Chinese property firms. Journal of Real Estate Finance \& Economics, 56, 352-385. https://doi.org/10.1007/s11146-017-9622-3

Dunning, J. H. (1998). Location and the multinational enterprise: a neglected factor? Journal of International Business Studies, 29(1), 45-66. https://doi.org/10.1057/palgrave.jibs.8490024

Dunning, J. H. (2002). Relational assets, networks, and international business activities, Amsterdam, Pergamon.

Eichholtz, P. M. A., Gugler, N., \& Kok, N. (2011). Transparency, integration, and the cost of international real estate investments. Journal of Real Estate Finance \& Economics, 43, 152173. https://doi.org/10.1007/s11146-010-9244-5

Erdener, C., \& Shapiro, D. M. (2005). The internationalization of Chinese family enterprises and Dunning's eclectic MNE paradigm. Managament and Organization Review, 1(3), 411-436. https://doi.org/10.1111/j.1740-8784.2005.00021.x 
Falkenbach, H. (2009). Market selection for international real estate investments. International Journal of Strategic Property Management, 13(4), 299-308.

https://doi.org/10.3846/1648-715X.2009.13.299-308

Farzanegan, M. R., \& Fereidouni, H. G. (2014). Does real estate transparency matter for foreign real estate investments? International Journal of Strategic Property Management, 18(4), 317-331. https://doi.org/10.3846/1648715X.2014.969793

Globerman, S., \& Shapiro, D. (2002). Global foreign direct investment flows: the role of governance infrastructure. World Development, 30, 1899-1919.

https://doi.org/10.1016/S0305-750X(02)00110-9

He, C., Wang, J., \& Cheng, S. (2009). What attracts foreign direct investment in China's real estate development? The Annals of Regional Science, 46(2), 267-293.

https://doi.org/10.1007/s00168-009-0341-4

He, C., \& Zhu, Y. (2010). Real estate FDI in Chinese cities: local market conditions and regiornal institutions. Eurosian Geography and Economics, 51(3), 360-384.

https://doi.org/10.2747/1539-7216.51.3.360

Huang, J., \& Rong, Z. (2017). Housing boom, real estate diversification, and capital structure: evidence from China. Emerging Markets Review, 32, 74-95.

https://doi.org/10.1016/j.ememar.2017.05.008

Hui, E. C. M., \& Chan, K. K. K. (2014). Foreign direct investment in China's real estate market. Habitat International, 43, 231-239. https://doi.org/10.1016/j.habitatint.2014.04.007

Jiang, D., Chen, J., \& Isaac, D. (1998). The effect of foreign investment on the real estate industry in China. Urban Studies, 35(11), 2101-2110. https://doi.org/10.1080/0042098984024

Jones Lang LaSalle. (2018). Global Real Estate Transparency Index 2018: transparency: data, disclosure and disruption. London: Jones Lang LaSalle.

KnightFrank. (2015). Chinese outward real estate investment globally and into Australia (pp. 1-12). Sydney: KnightFrank.

Kolstad, I., \& Wiig, A. (2012). What determines Chinese outward FDI? Journal of World Business, 47, 26-34. https://doi.org/10.1016/j.jwb.2010.10.017

Lau, H. F. (2003). Industry evolution and internationalization processess of firms from a newly industrialized economy. Journal of Business Research, 56(10), 847-852. https://doi.org/10.1016/S0148-2963(02)00472-1

Lee, C. L., Robinson, J., \& Reed, R. (2008). Listed property trusts and downside systematic risk sensitivity. Journal of Property Investment and Finance, 26(4), 304-328. https://doi.org/10.1108/14635780810886627

Lee, C. L., Stevenson, S., \& Lee, M. (2018). Low-frequency volatility of real estate securities and macroeconomic risk. Accounting and Finance, 58(S1), 311-342. https://doi.org/10.1111/acfi.12288

Liu, G., Li, K., Shrestha, A., Martek, I., \& Zhou, Y. (2018). Strategic business model typologies evident in the Chinese realestate industry. International Journal of Strategic Property Management, 22(6), 501-515.

https://doi.org/10.3846/ijspm.2018.6275

Lucke, N., \& Eichler, S. (2016). Foreign direct investment: the role of institutional and cultural determinants. Applied Economics, 48(11), 935-956.

https://doi.org/10.1080/00036846.2015.1090551

Newell, G., \& Lee, C. L. (2011). The impact of alternative assets on the role of direct property in Australian mixed-asset portfolios. Pacific Rim Property Research Journal, 17(4), 531-559. https://doi.org/10.1080/14445921.2011.11104341
Newell, G. (2016). The changing real estate market transparency in the European real estate markets. Journal of Property Investment \& Finance, 34(4), 407-420.

https://doi.org/10.1108/JPIF-07-2015-0053

PricewaterhouseCoopers. (2017). Tax guide 2017: tax havens. PricewaterhouseCoopers.

Quer, D., Claver, E., \& Rienda, L. (2012). Political risk, cultural distance, and outward foreign direct investment: empirical evidence from large Chinese firms. Asia Pacific Journal of Management, 29, 1089-1104.

https://doi.org/10.1007/s10490-011-9247-7

Ramasamy, B., \& Yeung, M. (2010). The determinants of foreign direct investment in services. World Economy, 33(4), 573-596. https://doi.org/10.1111/j.1467-9701.2009.01256.x

Real Capital Analytics. (2017). Chinese cross-border real estate investments. New York: Real Capital Analytics.

Rodriguez, C., \& Bustillo, R. (2010). Modeling foreign direct real estate investment: the Spanish case. Journal of Real Estate Finance \& Economics, 41(3), 354-367.

https://doi.org/10.1007/s11146-008-9164-9

Rogers, D., Lee, C. L., \& Yan, D. (2015). The politics of foreign investment in Australian housing: Chinese investors, translocal sales agents and local resistance. Housing Studies, 30(5), 730-748. https://doi.org/10.1080/02673037.2015.1006185

Rong, Z., Wang, W., \& Gong, Q. (2015). Housing price appreciation, investment opportunity and firm innovation: evidence from China. Journal of Housing Economics, 33, 34-58.

Shah, S. H., Ahmad, M. H., \& Ahmed, Q. M. (2016). The nexus between sectoral FDI and institutional quality: empirical evidence from Pakistan. Applied Economics, 48(17), 1591-1601. https://doi.org/10.1080/00036846.2015.1103039

Stevenson, S. (2008). Modeling housing market fundamentals: empirical evidence of extreme market conditions. Real Estate Economics, 36(1), 1-29.

https://doi.org/10.1111/j.1540-6229.2008.00204.x

Tang, J., Ye, K., \& Qian, Y. (2019). Rethinking the relationship between housing prices and inflation: new evidence from 29 large cities in China. International Journal of Strategic Property Management, 23(3), 142-155. https://doi.org/10.3846/ijspm.2019.7800

Tiezzi, S. (2014). China urges companies to 'Go Global'. The Diplomat. Retrieved from http://thediplomat.com/2014/12/ china-urges-companies-to-to-global/.

UNCTAD. (2017). World Investment Report 2017. Geneva, UNCTAD.

Weng, Y., \& Gong, P. (2017). On price co-movement and volatility spillover effects in China's housing markets. International Journal of Strategic Property Management, 21(3), 240255. https://doi.org/10.3846/1648715X.2016.1271369

Yeung, H. W. C. (1999). The internationalization of ethnic Chinese business firms from Southeast Asia: strategies, processes and competitive advantage. International Journal of Urban and Regional Research, 3(1), 103-127. https://doi.org/10.1111/1468-2427.00181

Zhan, J. X. (1995). Transnationalization and outward invesment: the case of Chinese firms. Transnational Corporations, 4(3), 67-100.

Zhu, J., Sim, L., \& Zhang, X. (2006). Global real estate investments and local cultural capital in the making of Shanghai's new office locations. Habitat International, 30(3), 462-481. https://doi.org/10.1016/j.habitatint.2004.12.003 


\section{Appendix}

Table A1. List of sample countries \& regions

\begin{tabular}{|c|c|c|c|c|}
\hline \multicolumn{5}{|c|}{ Countries } \\
\hline Australia & France & Israel & Palau & Sweden \\
\hline Austria & Germany & Japan & Philippines & Twitzerland \\
\hline Belgium & Greece & Kenya & Poland & Thailand \\
\hline Brazil & Hong Kong & Korea & Portugal & The Bahamas \\
\hline Canada & Hungary & Macau & Russia & Ukraine \\
\hline Croatia & Iceland & Malaysia & Singapore & United Arab Emirates \\
\hline Czech Republic & Indonesia & Mexico & South Africa & United Kingdom \\
\hline Denmark & Ireland & Netherlands & Spain & United States \\
\hline Ethiopia & Italy & New Zealand & Sri Lanka & \\
\hline
\end{tabular}

